\title{
FORENSIC MEDICAL AND LEGAL ASPECTS OF THE PROVISION OF MEDICAL CARE IN OBSTETRICS AND GYNECOLOGY
}

\author{
Pletenetska A.O. \\ Bogomolets national medical university, Kyiv, Ukraine \\ fantasyalinka@gmail.com
}

Relevance. Sometimes statistics on medical errors are hushed up, and information about individual incidents becomes known thanks to the media.

Objective: to identify the most common obstetric-gynecological profile defects and their causes by analyzing the data of the State Statistics Service on maternal and infant mortality during pregnancy, childbirth and the postpartum period and compare it with the forensic analysis of obstetric-gynecological profile medical care.

Materials and methods. 625 cases were analyzed according to the State Statistics Service on maternal and infant mortality during pregnancy, childbirth and the postpartum period, court sentences in criminal cases under Articles 139 and 140 of the Criminal Code of Ukraine, according to the Unified State Register of Court Decisions of Ukraine since 2009 in 2019, as well as data from forensic medical examination commissions on "medicinal matters" for 2013-2019 performed by the State Institution "Main Bureau of Forensic Medical Examination of the Ministry of Health of Ukraine", including cases of previous departmental audits by the commissions of the Health Administration. The data obtained were subjected to statistical processing by standard methods of descriptive statistics.

Results. In these 255 examinations, defects in the provision of medical care were found by expert commissions in 186 cases, which amounted to $72.9 \%$. Moreover, of these «defective cases», $62.9 \%$ (117 cases) were in a direct causal relationship with an unfavorable outcome; $35.5 \%$ (6 cases) - in some deficiencies that did not have a causal relationship with the onset of fetal death. In 3 cases of examinations in gynecology, there were contradictions in the entries in the medical documentation, they did not allow assessing the quality of medical care and the relationship with the consequences. At the pre-hospital stage (in the clinic), defects were allowed in $65.5 \%$, and at the hospital - in $72.8 \%$. In the presence of departmental inspections in $23 \%$, there was a complete coincidence of the results of the conclusions of the commissions of the bureau of forensic medical examination and medical examination, and only in cases of significant defects in direct causal connection with the consequences. At the same time, when analyzing 53 court sentences according to the register of court decisions, it turned out that 13 of them related to the obstetric and gynecological profile, and 12 of them were indictment. In all cases, the source of evidence in cases was exclusively the "Expert Conclusions".

Conclusions. It was found that forensic medical examinations for the provision of obstetric and gynecological medical care occupy a leading place in the overall structure of commission examinations in "medical matters", in the vast majority of examinations, defects in the provision of medical care were found that were in direct causal connection with an unfavorable outcome.

Key words: forensic medical examination, obstetrics, gynecology, defect, provision of medical care.

Relevance. The problem of so-called «medical errors» is relevant even in highly developed countries. For example, in 1999, the US Institute of Medicine published a report entitled «To Err Is Human», which announced that up to 98,000 Americans die each year from medical errors [1]. However, despite the measures taken by Congress (systematic courses and training for medical staff, strengthening control over the work of physicians through the establishment of special commissions), in 2019 medical errors remained just as common. Among the WHO findings: About $10 \%$ of hospitalized patients worldwide suffer from nosocomial infections. Medical errors occur in approximately $40 \%$ of primary and outpatient patients. Diagnostic and treatment errors are detrimental to millions and cost billions of dollars each year. According to researchers at Johns Hopkins University, 250,000 Americans die each year from medical errors, although no official statistics are available. In Ukraine, official statistics on medical errors are silenced, and information about individual incidents becomes known through the media $[4,5,6]$. It is a clear fact that such errors are common in those areas of medical practice that are associated with emergency surgery, such as obstetrics and gynecology, surgery, anesthesiology [7]. While in Europe and America the issue of correctness of medical care is solved by doctors of a certain specialty and lawyers [8], in Ukraine these issues are dealt with by forensic experts, which is emphasized by our legislation $[9,10,11]$.

However, in the presence of a complaint from relatives or other persons about poor quality treatment to the Ministry of Health, departmental inspections are carried out, where the commission of doctors of the Health Departments (HD) determines the correctness of medical care in a particular case. Only in the presence of a complaint to law enforcement agencies is a forensic medical examination appointed in the framework of criminal proceedings under Articles 139 and 140 of the Criminal Code of Ukraine. In order to accurately assess the correctness of medical care, in particular, obstetrics and gynecology, which is the most common among 
these examinations, it is necessary to analyze the most common defects and their causes.

Objective: taking into account the above, was to analyze the data of the State Statistics Service on maternal and infant mortality during pregnancy, childbirth and the postpartum period and compare it with the analysis of «Expert Conclusions» in cases of evaluation of obstetric and gynecological care.

\section{MATERIALS AND METHODS}

The material of the research was the data of the State Statistics Service on maternal and infant mortality during pregnancy, childbirth and the postpartum period (625), court verdicts in criminal cases under Articles 139 and 140 of the Criminal Code of Ukraine according to the Unified State Register of Judgments of Ukraine (USRJU) from 2009 to 2019, as well as 255 commission forensic medical examinations on «medical cases» for 2013-2019 («Expert conclusions»), performed in the «Main Bureau of Forensic Medical Examination of the Ministry of Health of Ukraine» (MB), including in cases of previous departmental inspections by commissions HD.

The obtained data were subjected to statistical processing by standard methods of descriptive statistics.

\section{RESEARCH RESULTS AND THEIR DISCUSSION}

According to the State Statistics Service, mortality during pregnancy, childbirth and the postpartum period (062 Class XV) tends to decrease from 69 in 2014 to 39 in 2018 (excluding the temporarily occupied territory of the Autonomous Republic of Crimea, Sevastopol and parts of the temporarily occupied territories in Donetsk and Luhansk regions since 2014) [12] (table 1).
During the statistical analysis of the commission forensic medical examinations of the Main Bureau of Forensic Medical Examination of the Ministry of Health of Ukraine regarding the obstetrics and gynecology profile for 2013-2019, conducted personally, it was found that forensic medical examinations for medical care occupy $27.2 \%$ in the general structure of all commission examinations - (table 2).

Forensic medical examinations for the provision of obstetric and gynecological medical care occupy a leading place in the overall structure of commission examinations for «medical cases» $-23.1 \%$ (255 cases).

A detailed analysis of such examinations revealed that the average age of examined women was 31 years of age, ie of working age and childbearing age.

In these 255 examinations, defects in the provision of medical care were found by expert commissions in 186 cases, which amounted to $72.9 \%$. And of these «defective cases» $62.9 \%$ (117 cases) of them were in direct causal connection with an adverse outcome; $35.5 \%$ (6 cases) some defects that were not causally related to the onset of fetal death. In 3 cases of gynecological examinations, there were discrepancies in the records in the medical records, which did not allow to assess the quality of medical care and the connection with the consequences.

$83.9 \%$ (214 cases) were obstetric, and almost half of them, $47.7 \%$ (102 cases), had defects in the provision of medical care that were directly causally related to the adverse outcome. Of these, the commissions of experts identified the following defects in the provision of medical care: $46.1 \%$ (47) of examinations, the defects in the provision of medical care were directly causally related to the death of the child; in $22.5 \%$ (23) - with extirpation of the uterus (severe injuries) and the onset

Table 1

Distribution of deaths by causes of death during pregnancy, childbirth and the postpartum period for 2013-2018 according to the State Statistics Service

\begin{tabular}{|l|c|c|c|c|c|c|}
\hline \multicolumn{1}{|c|}{ Causes of death } & $\mathbf{2 0 1 3}$ & $\mathbf{2 0 1 4}$ & $\mathbf{2 0 1 5}$ & $\mathbf{2 0 1 6}$ & $\mathbf{2 0 1 7}$ & $\mathbf{2 0 1 8}$ \\
\hline $\begin{array}{l}\text { 062 Class XV Pregnancy, childbirth and the postpartum } \\
\text { period O00-O99 }\end{array}$ & 65 & 69 & 60 & 46 & 30 & 39 \\
\hline 063 Pregnancy with abortive consequence O00-O08 & 2 & 3 & 3 & 2 & 1 & 1 \\
\hline $\begin{array}{l}\text { 064 Other direct causes of obstetric death (excluding } \\
\text { obstetric tetanus (A34)) O10-O92 }\end{array}$ & 35 & 41 & 30 & 32 & 18 & 24 \\
\hline $\begin{array}{l}\text { 065 Other complications of pregnancy, childbirth and the } \\
\text { postpartum period O95-O97 }\end{array}$ & 1 & 1 & - & - & - & - \\
\hline $\begin{array}{l}\text { 066 Indirect causes of obstetric death (excluding human } \\
\text { immunodeficiency virus (HIV) disease (B20-B24)) } \\
\text { O98-O99 }\end{array}$ & 27 & 24 & 27 & 19 & 11 & 14 \\
\hline
\end{tabular}

Table 2

The number of forensic medical examinations according to the State Institution «MB» for 2013-2019

\begin{tabular}{|c|c|c|c|c|c|c|c|}
\hline & 2013 & 2014 & 2015 & 2016 & 2017 & 2018 & 2019 \\
\hline The total number of examinations & 633 & 641 & 663 & 752 & 511 & 446 & 421 \\
\hline $\begin{array}{l}\text { Number of examinations for "medical } \\
\text { cases" }\end{array}$ & 149 & 151 & 145 & 147 & 205 & 153 & 157 \\
\hline $\begin{array}{l}\text { Number of obstetric and gynecological } \\
\text { examinations }\end{array}$ & 25 & 21 & 37 & 46 & 27 & 47 & 52 \\
\hline
\end{tabular}


of fetal death; in $15.7 \%$ (16) - with the onset of severe consequences in both women and children (severe injuries in both); in $9.8 \%$ (10) - with central nervous system damage in a child (severe injuries); other cases (8): shortcomings during abortion in direct causal connection with the onset of severe consequences (removal of the kidney) - severe injuries and when untimely diagnosis of fetal malformations led to the impossibility of timely termination of pregnancy

15 examinations concerned neonatology, among which in most cases (10) there was a direct causal link between defects in medical care and the death of the child.

Of the defects, in all cases there were incorrectly chosen tactics of childbirth, as well as in most cases -125 cases out of 186 cases with defects $(67.2 \%)$ - untimely provision or failure to provide medical care. The reason for the incorrectly chosen tactics of childbirth was underexamination of pregnant women, underestimation of survey data (for example, the case when a physiologically narrow pelvis doctor-obstetrician-gynecologist decided to "let in physiological childbirth», which resulted in death and serious injuries to the mother). In all these cases, doctors had a real opportunity to prevent serious consequences, as 98 cases occurred in large cities of Ukraine (the hospitals had all the necessary equipment and specialists).

When assessing the provision of medical care at different stages, it was found that at the pre-hospital stage (in the clinic) defects were allowed in 45 cases (24.2\%), and at the hospital - in 141 cases $(75.8 \%)$, in particular, during resuscitation measures.

When analyzing 255 of these examinations for obstetrics and gynecology, it was found that in the vast majority of cases $-223(87.5 \%)$ of all examinations for obstetrics received by the $\mathrm{MB}$, contained the conclusions of departmental commissions of the HD.

Upon closer examination of such examinations and comparison of results, it was found that only in 51 cases $(22.8 \%)$ there was a complete coincidence of the conclusions of the commissions of the Bureau of Forensic Medicine and the HD, and only in cases of significant defects that were in direct causal connection with the consequences. In other cases, the departmental commissions of the HD did not find defects in the provision of medical care, when, according to the results of forensic examinations, the defects were still present and led to serious consequences for women and / or children (death, serious injuries). It should be noted that the analysis of the conclusions of the HD commissions found that in almost all cases the commissions included doctors who were in one way or another connected with the accused medical workers (for example, were their supervisors or simply worked with them in the same institution).

At the same time, an analysis of 53 court verdicts according to the USRJU revealed that 13 of them were related to obstetrics and gynecology, and 12 of them were convictions [13]. In all cases, the source of evidence in the cases was exclusively the «Expert Conclusions», which clearly stated the existence of a defect in the provision of medical care, its connection with the consequence and the possibility of preventing this consequence.

It should be noted that in addition to the lack of a single algorithm of expert actions, which would be clearly indicated in the relevant document, complicate the forensic assessment of the quality of care such factors as: lack of certain protocols for care (eg, obstetric protocols in thrombosis and embolism during or after childbirth, etc.), which could facilitate forensic assessment of medical care in certain circumstances, poorly completed medical records of the victim, lack of information about the woman's health before pregnancy or the development of pathological conditions, electronic documentation.

\section{CONCLUSIONS}

1. In conducting our own research, it was found that forensic medical examinations for obstetrics and gynecology occupy a leading place in the overall structure of commission examinations for «medical cases», in the vast majority of examinations revealed defects in medical care were in direct causal consequential connection with an adverse consequence. This underscores the low level of obstetric and gynecological care in Ukraine.

2. A small percentage $(22.8 \%)$ of the coincidence of the results of the commissions of the Bureau of Forensic Medical Examination and the Health Departments in cases of obstetric and gynecological medical care in Ukraine may be due to biased assessment of medical care by the commissions of the Health Departments, which violates the principles of impartiality and legality of assessment.

3. In our opinion, need to develop and implement in practice «Rules of forensic examinations in cases of bringing medical workers to justice for» professional offenses «by the relevant competent institutions (« Main Bureau of Forensic Medicine of the Ministry of Health of Ukraine «), and procedural regulation of the seizure of electronic medical records by law enforcement officials for forensic examination, which will improve the quality of such examinations in Ukraine and increase the level of detection of crimes in the field of medical care.

Конфлікт інтересів: відсутній/ Conflicts of interest: authors have no conflict of interest to declare. Надійшла до редакції / Received: 05.05.2020 Прийнято до друку / Accepted: 29.06.2020

REFERENCES

1. Kohn LT, Corrigan JM, Donaldson MS. To Err is Human: Building a Safer Health System // Institute of Medicine (US) Committee on Quality of Health Care in America. Washington (DC): National Academies Press (US). 2000, 1 (1). PMID: 25077248. DOI: https://www. ncbi.nlm.nih.gov/pubmed/25077248

2. Kathleen Sutcliffe. The Health Care Industry Needs to Be More Honest About Medical Errors // Time USA. 2019 Nov 05. URL: https://time.com/5717545/medicalerrors/ 
3. [In the United States, medical errors have been cited as one of the leading causes of death] // Interfax. 2016. [in Russian]. URL: http://www.interfax.ru/world/506759

4. [Medical error: causes and consequences] // Medical and legal portal «103-law.org.ua». 2012. [in Ukrainian]. URL: http://103-law.org.ua/Article.aspx?a=61

5. [In Ukraine there are no statistics of medical errors, - the expert] // Analytical online publication of Lviv «Zaxid.net». 2012. [in Ukrainian]. URL: https://zaxid. net/v_ukrayini_nema_statistiki_likarskih_pomilok ekspert_n1266352

6. [Medical error and how to deal with it] // Agency of regional information and analytics «galinfo.com. ua». 2013. [in Ukrainian]. URL: http://galinfo. com.ua/articles/likarska_pomylka_i_yak_z_neyu borotysya_125439.html

7. Bushmeleva N.N. [Defects in the provision of medical care in cases of maternal death at the regional level] // Electronic scientific journal «Social Aspects of Population Health». 2014. 3 (37). [in Russian]. URL: http://vestnik.mednet.ru/content/view/565/30/lang,ru/

8. Mateikovich EA, Shevlyukova TP, Kukarskaya EY, Galieva GD. [Medical errors in the provision of obstetric and gynecological care] // Modern problems of science and education. 2018. 5 (1). [in Russian]. URL: http:// www.science-education.ru/ru/article/view? $\mathrm{Id}=27991$

9. Steblyuk VV. [Legal and moral and ethical aspects of criminal offenses in the field of professional activity of medical workers] // Forensic examination. 2013. 2: 45-8. [in Ukrainian]. http://nbuv.gov.ua/UJRN/ sme_2013_2_14

10. Dunaevskaya LG. [Investigation of crimes committed during the provision of medical care]. Kyiv: UMCC Center; 2012. 168 p. [in Ukrainian]. ISBN 978-9668287-34-3.

11. Criminal Procedure Code of Ukraine // Information of the Verkhovna Rada of Ukraine (VVR). 2016. [in Ukrainian]. URL: http://zakon2.rada.gov.ua

12. Distribution of deaths by sex, age groups and causes of death $(0,1) / /$ Database of State Statistics of Ukraine. [in Ukrainian]. URL: http://database.ukrcensus.gov.ua/ Mult/Dialog/Saveshow.asp

13. Unified State Register of Judgments of Ukraine. 2020. [in Ukrainian]. URL: http://www.reyestr.court.gov.ua/

\title{
СУДОВО-МЕДИЧНІ ТА ПРАВОВІ АСПЕКТИ НАДАННЯ МЕДИЧНОЇ ДОПОМОГИ В АКУШЕРСТВІ ТА ГІНЕКОЛОГІЇ
}

\author{
Плетенецька А.O. \\ Начіональний медичний університет імені О.О. Богомольия, Київ, Украйна \\ fantasyalinka@gmail.com
}

Актуальність. Інколи статистика лікарських помилок замовчується, а інформація про окремі інциденти стає відомою завдяки засобам масової інформації.

Мета: встановлення найбільш частих дефектів акушерського-гінекологічного профілю та їх причин шляхом проведення аналізу даних Державної служби статистики щодо материнської смертності та смертності немовлят під час вагітності, пологів та післяпологового періоду і зіставити його з судово-медичним аналізом надання медичної допомоги акушерського-гінекологічного профілю.

Матеріали та методи. Проаналізовано 625 випадків за даними Державної служби статистики по материнській смертності та смертності немовлят під час вагітності, пологів та післяпологового періоду, судові вироки у кримінальних справах за статтями 139 і 140 Кримінального кодексу України, за даними Сдиного державного реєстру судових рішень України (ЄДРСР) з 2009 р по 2019 р, а також дані з комісійних судово-медичних експертиз за «лікарськими справами» за 2013-2019 рр., виконані в ДУ «Головне бюро судово-медичної експертизи МОЗ України», в тому числі у випадках попередніх відомчих перевірок комісіями Управління охорони здоров'я. Отримані дані піддавалися статистичній обробці стандартними методиками описової.

Результати. У зазначених 255 експертизах дефекти в наданні медичної допомоги були знайдені експертними комісіями в 186 випадках, що склало 72,9\%. Причому з цих «дефектних випадків» 62,9\% (117 випадки) знаходилися в прямому причинно-наслідковому зв'язку з несприятливим результатом; 35,5\% (6 випадків) - деякі недоліки, які не мали причинного зв'язку 3 настанням смерті плоду. У 3 х випадках експертиз по гінекології були протиріччя в записах в медичній документації, що не дозволяло оцінити якість надання медичної допомоги і зв'язок з наслідками. На догоспітальному етапі (в поліклініці) дефекти допускалися в $24,2 \%$, а на госпітальному - в $75,8 \%$. При наявності відомчих перевірок в $23 \%$ можна говорити про повний збіг результатів висновків комісій бюро судово-медичної експертизи і УОЗ, причому тільки у випадках суттєвих дефектів в прямому причинному зв'язку з наслідками. У той же час при аналізі 53 судових вироків за даними ресстру судових рішень виявилося, що 13 них стосуються акушерсько-гінекологічного профілю, причому 12 з них були обвинувальними. У всіх випадках джерелом доказів у справах були виключно «Висновки експерта».

Висновки. Було встановлено, що судово-медичні експертизи з надання медичної допомоги акушерсько-гінекологічного профілю займають провідне місце в загальній структурі комісійних експертиз по «лікарських справ», в переважній більшості експертиз виявлені дефекти надання медичної допомоги, що знаходилися в прямого причинно-наслідкового зв'язку з несприятливим результатом.

Ключові слова: судово-медична експертиза, акушерство, гінекологія, дефект, надання медичної допомоги. 


\title{
СУДЕБНО-МЕДИЦИНСКИЕ И ПРАВОВЫЕ АСПЕКТЫ ОКАЗАНИЯ МЕДИЦИНСКОЙ ПОМОЩИ В АКУШЕРСТВЕ И ГИНЕКОЛОГИИ
}

\section{Плетенецкая А.А.}

\author{
Наџиональный медичинский университет А.А. Богомольча, Киев, Украина \\ fantasyalinka@gmail.com
}

\begin{abstract}
Актуальность. Иногда статистика врачебных ошибок замалчивается, а информация об отдельных инцидентах становится известной благодаря средствам массовой информации.

Цель: установление наиболее частых дефектов акушерского-гинекологического профиля и их причин путем проведения анализа данных Государственной службы статистики по материнской смертности и смертности младенцев во время беременности, родов и послеродового периода и сопоставить его с судебно-медицинским анализом оказания медицинской помощи акушерско-гинекологического профиля.

Материалы и методы. Проанализировано 625 случаев, по данным Государственной службы статистики по материнской смертности и смертности младенцев во время беременности, родов и послеродового периода, судебные приговоры по уголовным делам по статьям 139 и 140 Уголовного кодекса Украины, по данным Единого государственного реестра судебных решений Украины (ЕГРСР) с 2009 г. по 2019 г., а также данные из комиссионных судебно-медицинских экспертиз по «лекарственными делами» за 2013-2019 гг., выполненные в ГУ «Главное бюро судебно-медицинской экспертизы МЗ Украины», в том числе и в случаях предыдущих ведомственных проверок комиссиями Управления охраны здоровья. Полученные данные подвергались статистической обработке стандартными методиками описательной статистики.

Результаты. В указанных 255 экспертизах дефекты в оказании медицинской помощи были найдены экспертными комиссиями в 186 случаях, что составило 72,9\%. Причем из этих «дефектных случаев» 62,9\% (117 случая) находились в прямом причинно-следственной связи с неблагоприятным исходом; 35,5\% (6 случаев) - в некоторые недостатки, которые не имели причинной связи с наступлением смерти плода. В 3х случаях экспертиз по гинекологии были противоречия в записях в медицинской документации, не позволяли оценить качество оказания медицинской помощи и связь с последствиями. На догоспитальном этапе (в поликлинике) дефекты допускались в $24,2 \%$, а на госпитальном - в 75,8\%. При наличии ведомственных проверок в $23 \%$ имело место полное совпадение результатов выводов комиссий бюро судебно-медицинской экспертизы и УОЗ, причем только в случаях существенных дефектов в прямой причинной связи с последствиями. В то же время при анализе 53 судебных приговоров по данным реестра судебных решений оказалось, что 13 из них касаются акушерско-гинекологического профиля, причем 12 из них были обвинительными. Во всех случаях источником доказательств по делам были исключительно «Выводы эксперта».

Выводы. Было установлено, что судебно-медицинские экспертизы по оказанию медицинской помощи акушерско-гинекологического профиля занимают ведущее место в общей структуре комиссионных экспертиз по «врачебным делам», в подавляющем большинстве экспертиз обнаружены дефекты оказания медицинской помощи, находившиеся в прямой причинно-следственной связи с неблагоприятным исходом.
\end{abstract}

Ключевые слова: судебно-медицинская экспертиза, акушерство, гинекология, дефект, оказания медицинской помощи. 